\title{
Sistem Pemantauan Perbaikan Faktor Daya Listrik Rumah Tangga Berbasis IoT
}

\author{
Giro Menanti B, Reza Himawan, dan Fauzun Atabiq \\ Politeknik Negeri Batam, Jurusan Teknik Elektro, Batam \\ E-mail: atabiq@polibatam.ac.id
}

\begin{abstract}
Abstrak
Perkembangan teknologi dan IT yang cepat akhir- akhir ini membuat masyarakat semakin erat berhubungan dengan perangkat pintar, big data, cloud, dan loT. Fenomena ini menyebar lebih cepat berdasarkan infrastruktur komunikasi kabel dan nirkabel yang disediakan untuk pemantauan dan pengaturan peralatan listrik kebanyakan tempat tinggal sebagai perangkat hubung komunikasi ke beberapa perangkat terminal dengan beragam fungsi. Dalam studi ini, sistem pemantauan dalam perbaikan faktor daya pada listrik rumah tangga telah dibuat terintegrasi dengan perangkat loT sehingga setiap setiap data parameter listrik dan status dari perbaikan faktor daya dapat diakses datanya secara realtime melalui aplikasi web yang bisa diakses dimana pun menggunakan perangkat elektronik seperti smartphone, notebook, laptop dan juga komputer. Dari hasil pengujian menunjukkan bahwa data faktor daya beserta data parameter listrik lainnya dapat diakses datanya secara realtime database dengan aplikasi web dan bisa diakses dimanapun menggunakan perangkat seperti android, notebook, laptop dan juga komputer.
\end{abstract}

Kata kunci: Perbaikan Faktor Daya, Internet of Things (IoT), Web, Monitoring, Realtime Database

\begin{abstract}
The fast development of technology and IT lately has made people more closely connected with smart devices, big data, cloud, and loT. The phenomenon is spreading faster based on the wired and wireless communication infrastructure provided for temperature and regulation of electrical equipment in most residential areas as a communication link device to several terminal devices with various functions. In this study, the fire system in improving the power factor of household electricity has been integrated with loT devices so that each electrical data parameter and status of the power factor improvement can be accessed in real time through a web application that can be accessed anywhere using electronic devices such as smartphones, notebooks, laptops and computers. The test results show that the power factor data along with other electrical data parameters can be accessed in a real-time database with a web application and can be accessed anywhere using devices such as androids, notebooks, laptops and also computers.
\end{abstract}

Keywords: Power Factor Improvements, Internet of Things (IoT), Web, Monitoring, real-time Database. 


\section{Pendahuluan}

Pada penelitian ini, ada beberapa peralatan yang akan digunakan untuk menampilkan data baik dalam pengukuran tegangan, arus, daya, serta faktor daya (cosphi) dari masingmasing beban (peralatan elektronik rumah tangga) yang terukur serta module komponen yang digunakan. Sistem nantinya akan menampilkan setiap data yang terukur dalam bentuk tabel data untuk analisa perubahan dan grafik data untuk melihat pergerakan perubahan data secara realtime, yang juga dilengkapi dengan status kapasitor pada saat sedang aktif maupun tidak aktif untuk mendukung proses perbaikan dalam jarak jauh [5].

Sistem pemantauan perbaikan faktor daya pada listrik ini terhubung dengan beberapa beban elektronik rumah tangga dengan memperhatikan faktor daya (cos phi) ketika beban sudah tersambung dengan alat [1]. Jika faktor daya listrik (cosphi) dibawah dari standar maka secara otomatis alat akan memperbaikinya lalu informasi akan dikirimkan web aplikasi dengan pencatatan waktu yang aktual. Sistem monitoring dilakukan dengan memanfaatkan jaringan internet sebagai media komuniksi antara alat perbaikan dengan sistem monitoring [2]. Dengan adanya rancangan ini diharapkan dapat mempermudah dalam monitoring faktor daya, arus ,tegangan, dan daya, karena sistem pemantauan ini dapat dilakukan dari jarak jauh dengan aplikasi web dillengkapi database yang terhubung dengan koneksi internet.[4,6]

\section{Metode Penelitian}

Untuk menunjang penyelesaian sistem yang akan dibangun ada beberapa tahapan yang perlu diperlukan, adapun tahapan tersebut adalah sebagai berikut:

a. Pendalaman literature metode yang digunakan dalam penelitian.

b. Perancangan dan pembuatan hardware (perangkat keras) sistem.

c. Perancangan dan pembuatan software (perangkat lunak) program pada mikrokontroler dan berbasis IOT.

d. Pengujian pada hardware beserta software yang sudah dibuat.

e. Melakukan anlisa dari algoritma yang digunakan untuk tingkat fungsionalitas

2 dan keakurasian aplikasi terhadap sistem pemantauan faktor daya listriknya dan mengirimkan datanya ke aplikasi web.

f. Penulisan Jurnal

\section{A. Deskripsi Sistem}

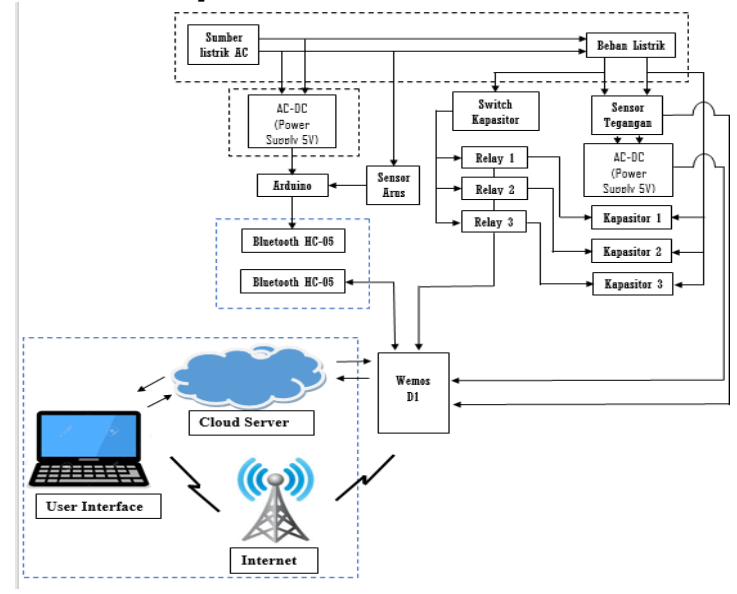

Gambar 1. Deskripsi Sistem

Pada Gambar 1 merupakan deskripsi dari sistem yang dibangun yaitu monitoring (Web IoT) dan alat perbaikan (terdiri dari device 1 dan device 2). Device 1 terdiri dari sensor tegangan, switch kapasitor, relay, kapasitor, wemos D1 Esp8266 dan power supply 5V, kemudian device 2 terdiri dari sensor arus, module bluetooth, arduino dan power supply 5V) [3,5]. Sumber arus listrik AC terhubung langsung dengan sensor arus dan beban listrik, sensor arus yang terintegrasi dengan arduino, kemudian arduino mengirimkan data arus ke device 1 (wemos D1 Esp8266) melalui module bluetooth.[5,6,10]

\section{B. Perancangan Perangkat Lunak}

Gambar 2 menjabarkan data pembacaan faktor daya yang ditransmisikan melalui jaringan Wi-Fi dan diterima oleh cloud server. Ketika start maka proses pendeklarasian file header dan variabel berjalan kemudian diikuti dengan proses pemeriksaan node pada program arduino. Proses pada flowchart yang selanjutnya adalah pemeriksaan koneksi akses point (menggunakan Wemos modul wifi ESP 8266 sebagai media komunikasi internet), ketika terhubung langsung melakukan pembacaan sensor lalu mengkonversi perhitungan arus dan tegangan untuk mendapatkan nilai cosphi (jika tidak terhubung dengan akses point maka akan kembali pada proses pemeriksaan koneksi akses point) $[8,10]$. 


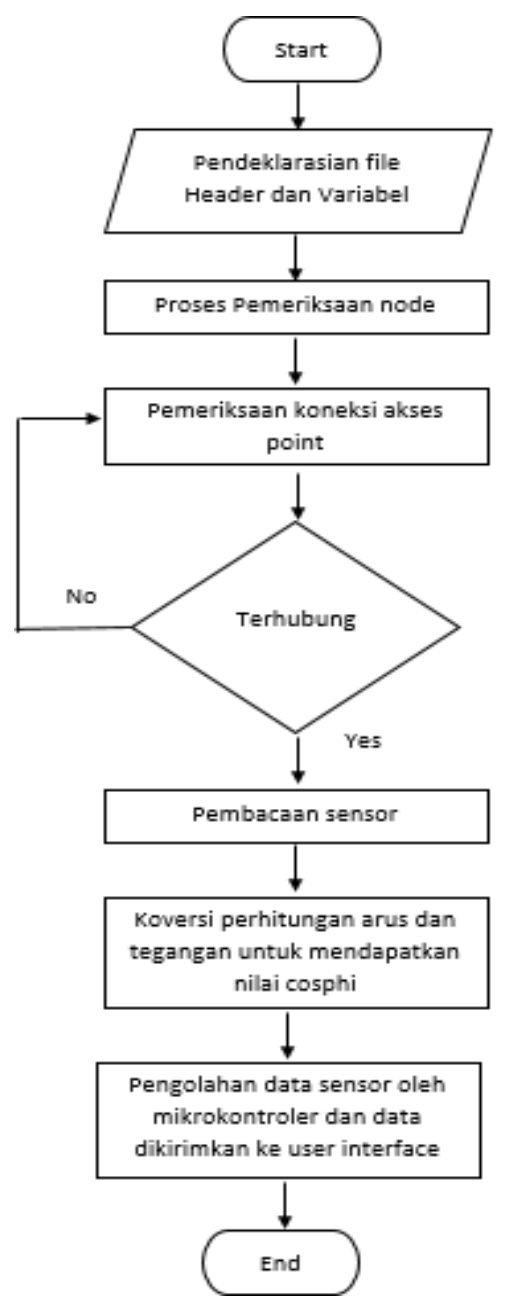

Gambar 2. Flowchart pembacaan faktor daya

Selanjutnya pengolahan data sensor oleh mikrokontroler dan data dikirimkan ke user interface (web hosting). Pada Gambar 3 adalah fungsi pencatatan, pengolahan data, serta penampilan dan akses data melalui jaringan internet, digunakan layanan web server phpMyAdmin yang merupakan open data platform untuk IoT. Data tersebut kemudian di proses oleh php dan jika diizinkan data akan tersimpan dalam database MySQL kemudian ditampilkan pada web browser yang sudah terintegrasi Internet of Things (IoT).

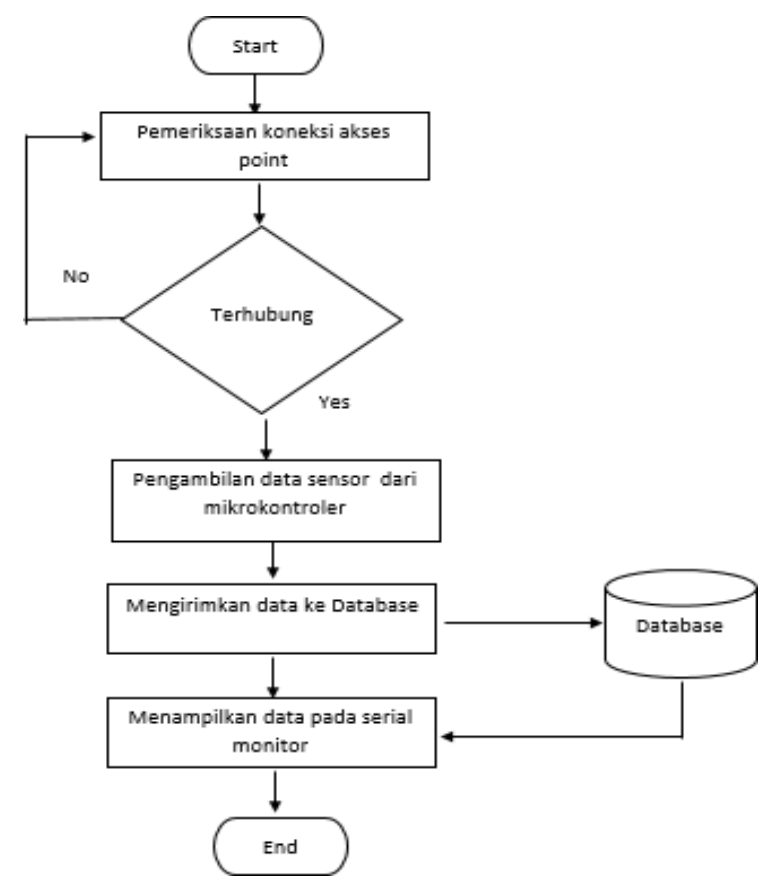

Gambar 3. Flowchart pembacaan faktor daya

\section{Hasil dan Diskusi}

\section{A. Aplikasi Web}

Aplikasi Web dibuat dengan menggunakan Visual Studio Code yang merupakan sebuah aplikasi teks editor yang sering dipakai para web developer. Aplikasi teks editor ini sudah mendukung teknologi serupa seperti HTML, CSS, Less, Saas dan JSON. Untuk tampilan web aplikasi yang telah dibuat dapat dilihat sebagai berikut.

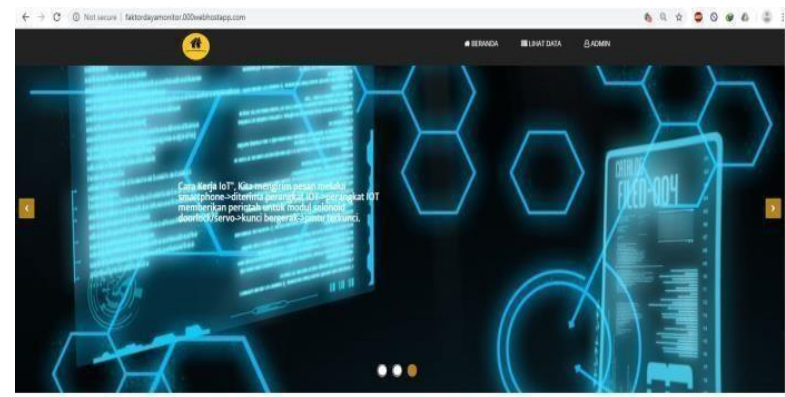

$$
8
$$

Gambar 4.Tampilan Laman akses web $\mathrm{d}$ laptop/komputer 


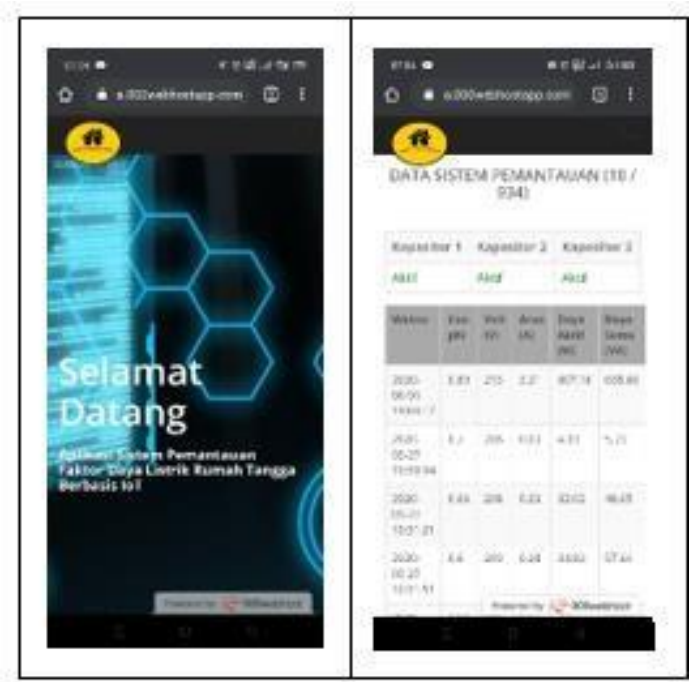

Gambar 5. Tampilan Laman akses web di android

Pada gambar 4 dan 5 adalah hasil dari sistem yang dibangun dengan konsep internet of things (IOT), agar sistem dapat diakses dimanapun dan kapan pun,dengan sistem yang di buat responsive terhadap semua perangkat.

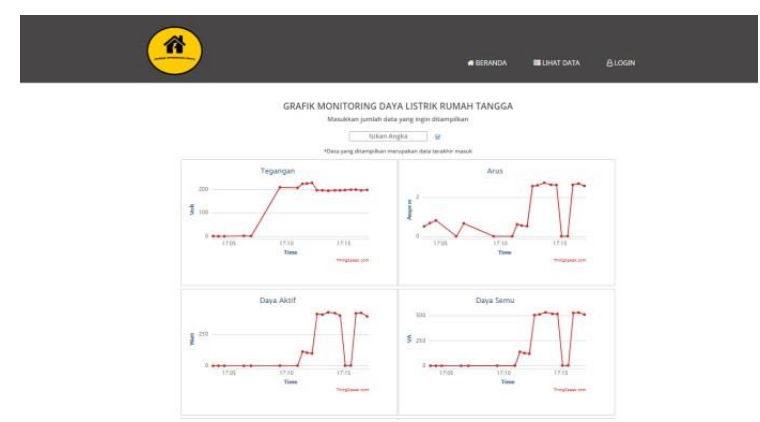

Gambar 6. Tampilan Data Berupa Grafik

Pengambilan data juga dapat dilakukan dengan grafik untuk memudahkan dalam pemantauan perubahan data yang diambil secara realtime.

\section{B. Pengujian Keseluruhan Sistem}

Pengujian dilakukan dengan menggunakan metode black box. Metode Black Box adalah metode pengujian dengan menguji fungsionalitas sistem dan mengamati hasil eksekusi melalui data uji. Pada pengujian ini, link website diakses pada daerah sekitar kota Batam dengan jumlah user yang mengakses sebanyak 36 orang. Pengujian dilakukan pada tanggal 29 Maret 2020 dengan metode pengumpulan datanya adalah metode kuesioner.

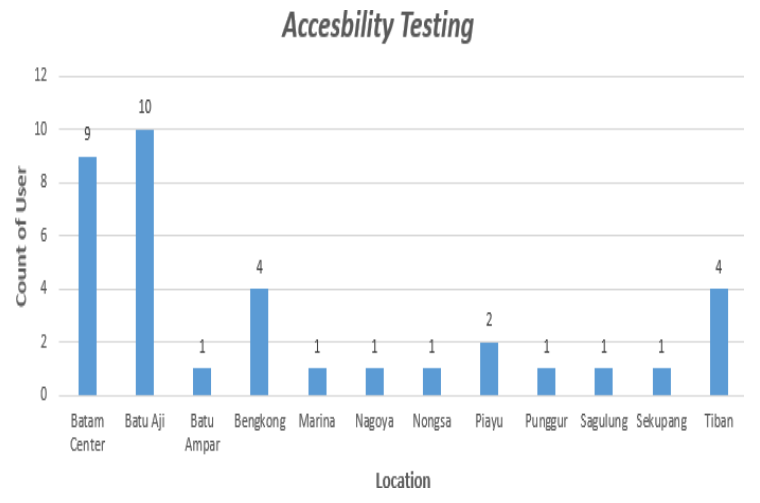

Gambar 7. Daerah user mengakses web

Compability Testing

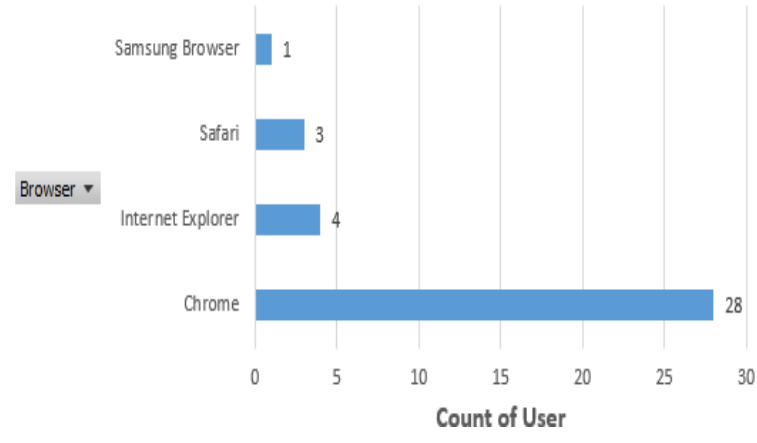

Gambar 8. Browser yang digunakan user

Gambar 8 menunjukkan bahwa browser yang lebih dominan digunakan oleh user adalah chrome sebanyak 28 user (77.8\%), internet explorer 4 user $(11.1 \%)$, safari 3 user $(8.3 \%)$ dan samsung browser 1 user (2.8\%). Hasil dari pengujian ini membuktikan bahwa website monitoring dapat diakses menggunakan browser yang berbeda sekalipun.

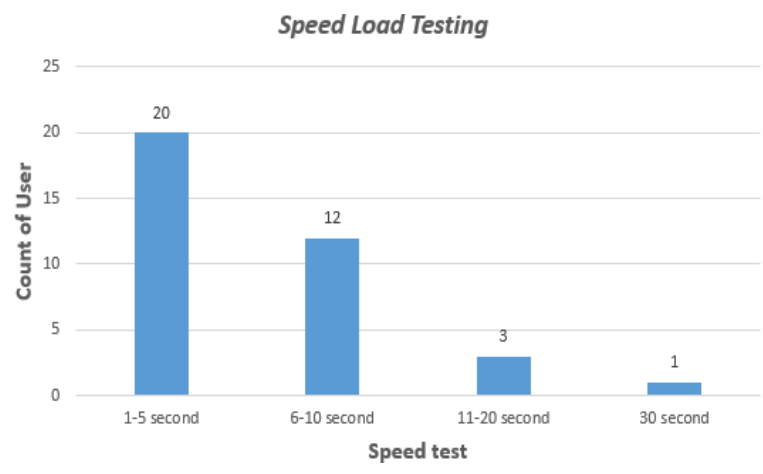

Gambar 9. Kecepatan dalam mengakses web

Pada Gambar 9 menunjukan paling waktu paling lama yang dibutuhkan dalam mengakses laman webiste adalah 30 detik, yang dimana pada pengujian kecepatan akses 
ini sangat di perangaruhi oleh koneksi internet, lokasi yang jauh sekali pun jika koneksi internet mendukung maka akses cepat web dapat dilakukan

\section{Kapasitas Penyimpanan Data}

Database yang digunakan disini merupakan database MySQL, dengan kapasitas penyimpanan data sebesar $300 \mathrm{MB}$ yang mampu menyimpan tipe data seperti tipe data numerik (Int/Integer), tipe data string (VarChar, Char) dan tipe data penanggalan dan waktu (Date Time). Untuk jumlah row record yang mampu ditampung oleh database sendiri bias dilihat padan table dibawah ini.

Tabel 1. Kapasitas Penyimpanan Data

\begin{tabular}{ccc}
\hline Jumlah Data & Date Time & Durasi Monitoring \\
\hline 45 & 27 Feruari 2020 & 50 menit \\
25 & 02 Mei 2020 & 20 menit \\
117 & 03 Mei 2020 & 80 menit \\
119 & 16 Mei 2020 & 180 menit \\
624 & 17 Mei 2020 & 600 menit \\
145 & 01 Juni 2020 & 240 menit \\
31 & 20 Juni 2020 & 15 menit \\
\hline
\end{tabular}

Pada Tabel 1 jumlah data record yang tersimpan pada database sebanyak 1106 data (74 kb) dari disk yang tersedia $300 \mathrm{MB}$.

\section{Hasil Pengujian Monitoring}

Data monitoring yang akan ditampilkan pada sistem berbasis internet of things terdiri dari Cosphi (faktor daya), arus listrik, tegangan listrik, daya aktif, daya semu, status kapasitor dan time stamp (waktu aktual yang tertera pada saat monitoring berlangsung).

\begin{tabular}{|c|c|c|}
\hline bescistal & lepsitur? & Ensitus? \\
\hline kt & kt & Ht \\
\hline
\end{tabular}

Gambar 10. Tampilan status kapasitor

Pada Gambar 10 sistem menampilkan status kapasitor untuk membantu pembacaan informasi dalam perbaikan cosphi (faktor daya listrik). Berikut ini merupakan parameter kapasitor yang digunakan [9].

- Kapasitor 1 bernilai: 14 uF/400Volt

- Kapasitor 2 bernilai: 16 uF/400Volt

- Kapasitor 3 bernilai: 32 uF/300Volt

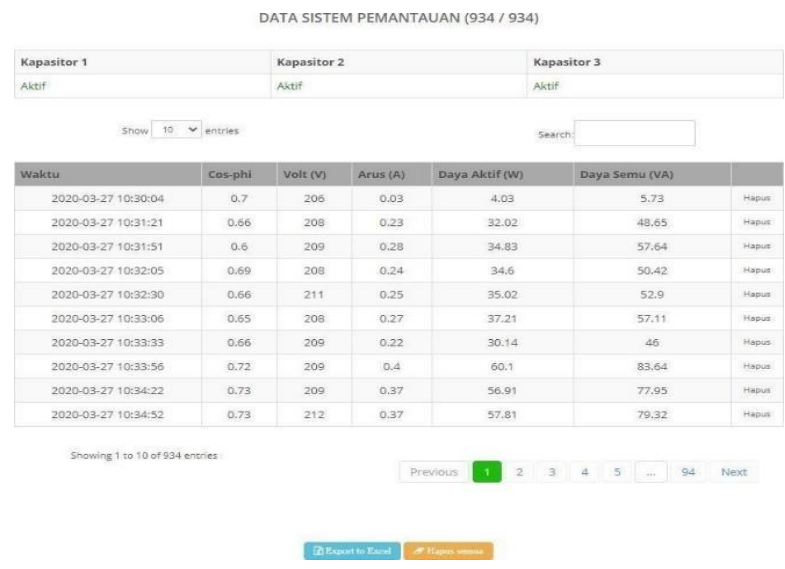

Gambar 11. Data pengujian mesin cuci dan setrika

Data pada Gambar 11 menggunakan kipas angin dengan parameter: Merk Cosmos, kipas angin berdiri 16", ukuran baling-baling 40CM/16 Inc, kecepatan angin: $220 \mathrm{M} / \mathrm{Min}$, Daya Masukan: 46 Watt, Tegangan Frekuensi:220V $50 \mathrm{~Hz}$ sebagai beban pengujian alat perbaikan, dimana data parameter yang ditampilkan pada web adalah seperti waktu, cosphi, tegangan, arus, daya aktif, daya semu dan status kapasitor. Setiap 5 detik sekali web akan secara otomatis refresh page untuk menampilkan setiap data baru yang masuk (jika terjadi perubahan/penambahan data).

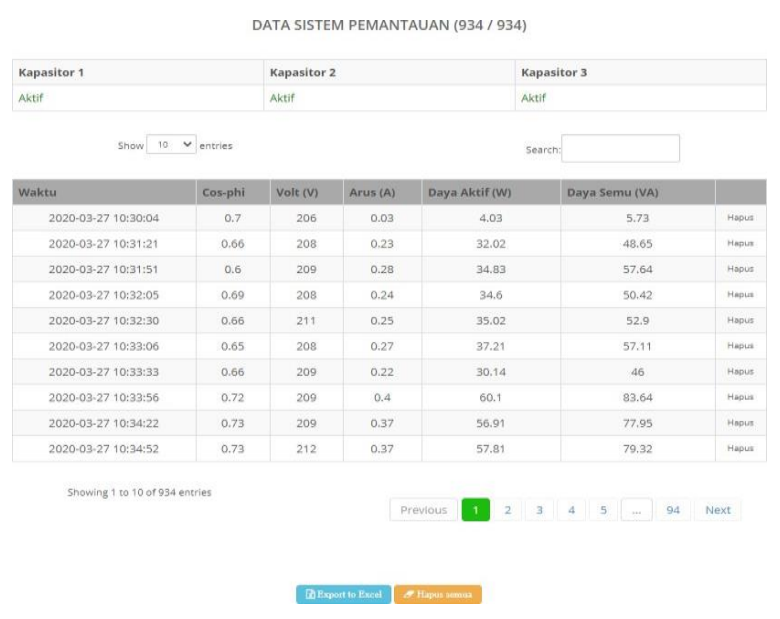

Gambar 12. Data pengujian kipas angin

Data pada Gambar 12 menggunakan kipas angin dengan parameter: Merk Cosmos, kipas angin berdiri 16", ukuran baling-baling $40 \mathrm{CM} / 16$ Inc, kecepatan angin: $220 \mathrm{M} / \mathrm{Min}$, Daya Masukan: 46 Watt, Tegangan Frekuensi:220V $50 \mathrm{~Hz}$ sebagai beban pengujian alat perbaikan, dimana data parameter yang ditampilkan pada web adalah seperti waktu, cosphi, tegangan, arus, daya aktif, daya semu dan status kapasitor. Setiap 5 detik sekali web akan secara otomatis 
refresh page untuk menampilkan setiap data baru yang masuk (jika terjadi perubahan/penambahan data).

\section{Simpulan}

Sistem pemantauan perbaikan faktor daya listrik rumah tangga telah berhasil dikembangkan. Dari hasil pengujian sistem pemantauan yang dikembangkan pada penelitian ini menunjukkan accesbility testing system yaitu mampu diakses di daerah-daerah yang sudah diuji menggunakan berbagai jenis perangkat yang berbeda dan juga tidak membatasi jumlah pengakses pada system. Untuk speed load testing didapat data dengan kecepatan akses tercepat yaitu 5 detik yang membuktikan bahwa system bagus dalam performa kecepatan. Content testing pada system berhasil membuktikan bahwa data monitoring pada sistem di tampilkan sesuai dengan yang diharapkan dengan fitur yang ditambahkan berfungsi dengan baik. Compability testing pada system ini berhasil membuktikan bahwa system dapat diakses urnya di browser manapun seperti pada data pengujian. Kapasitas penyimpanan data system ini dilengkapi dengan disk $300 \mathrm{Mb}$ yang mampu menyimpan lebih banyak data bias mencapai seribu data sekali proses monitoring berjalan. Search data berfungsi dengan semestinya dengan system pencarian ini dapat memudahkan pencarian data tertentu. Hasil pemantauan penelitian ini juga menunjukkan bahwa dengan mengaktifkan kapasitor bank pada instalasi listrik rumah tangga dapat memperbaiki faktor daya penggunaan listrik berkisar 0.7 s. d. 0.8

\section{Ucapan Terima Kasih}

Ucapan terima kasih kepada kedua orang tua dan keluarga atas jasa, doa, bimbingan dan nasehat. Fauzun Atabiq. Selaku dosen pembimbing yang telah menyediakan waktu dan pikiran untuk mengarahkan penulis dalam menyelesaikan penelitian ini. Seluruh staf pengajar dan administrasi di jurusan Teknik Elektro Politeknik Negeri Batam. Seluruh teman-teman seperjuangan Teknik Mekatronika angakatan 2016. Semua pihak yang telah membantu penulis dalam menyelesaikan jurnal ini yang tidak dapat penulis sebutkan satu persatu.

\section{Daftar Pustaka}

[1] J. Grafika and Y. Indonesia, "Studi perbaikan faktor daya beban induktif dengan kompensator reaktif seri menggunakan sakelar pemulih energi magnetik," pp. 125-147.

[2] P. Fisika, "Rancang Bangun Sistem Proteksi dan Monitoring Penggunaan Daya Listrik Pada Beban Skala Rumah Tangga Berbasis Mikrokontroler ATMega328P," vol. VI, no. 01, pp. 26-33, 2018.

[3] A. Z. Ebim Iskandar Muda, Raden Arief Setyawan, "Perbandingan Data Sensor Arus Sct 013 Dan Sensor Arus Acs 712 Pada Pengukuran Arus Listrik," Univ. Brawijaya, vol. 5, p. 5, 2017.

[4] A. Tanjung, R. Pramana, S. Nugraha, and M. Eng, "Prototipe Sistem Monitoring Daya Pada Kwh Meter 1 Phase Dan Sistem Kontrol On / Off Via Sms Module," Tek. Elektro Umr., pp. 1-7, 2017.

[5] U. Suryadarma, "Jurnal Teknologi Elektro, Universitas Mercu Buana RANCANG Bangun Sistem Keamanan Rumah Menggunakan Relay Muhamad Saleh Program Studi Teknik Elektro Universitas Suryadarma , Jakarta Program Studi Teknik Elektro ISSN : 2086 - 9479," Tek. Elektro, vol. 8, no. 3, pp. 181-186, 2017.

[6] S. Graha, "Rancang Bangun Perbaikan Faktor Daya," no. 2, 2014.

[7] S. Noor and N. Saputera, "Kapasitor Bank," vol. 6, no. 2, pp. 1-6, 2014.

[8] B. A. B. li and T. Pustaka, "Pembahasan Mengenai Mikrokontroler," Polsri, pp. 439, 2013.

[9] Admin, "Fungsi Kapasitor Elco Dan Pengertian Lengkap," Rangkaian Elektron., vol. 1, p. 1, 2016.

[10] A. Sanjaya, "Konfigurasi Pin Wemos D1 Esp8266," blog adi sanjaya glob. techno Solut., vol. 3, p. 5, 2017. 